\title{
DETEKSI DAN IDENTIFIKASI Austropuccinia psidii PADA MYRTACEAE DI YOGYAKARTA INDONESIA
}

\author{
Detection and identification of Austropuccinia psidii on Myrtaceae in Yogyakarta Indonesia
}

\author{
Istiana Prihatini1 ${ }^{1}$, ILG. Nurtjahjaningsih ${ }^{1}$, Farah Aulya Faradilla ${ }^{2}$ dan Suranto ${ }^{2}$ \\ 1,2Kontributor Utama, ${ }^{1}$ Balai Besar Penelitian dan Pengembangan Bioteknologi dan Pemuliaan Tanaman Hutan \\ Jl. Palagan Tentara Pelajar KM 15, Purwobinangun, Pakem, Sleman, Yogyakarta, Indonesia \\ email penulis korespondensi : istiana.prihatini@yahoo.co.id \\ ${ }^{2}$ Universitas Sebelas Maret Surakarta \\ J1. Ir. Sutami No.36A, Surakarta, Jawa Tengah, Indonesia
}

Tanggal diterima: 16 Desember 2020, Tanggal direvisi: 18 Desember 2020, Disetujui terbit: 24 Desember 2020

\begin{abstract}
Austropuccinia psidii is a pathogenic fungus that causes rust in the Myrtaceae plant. The extensive plantation of the host of this fungus has increased the attack of fungal pathogen, therefore, it will increase the threat to the presence of Myrtaceae species around the globe including in Indonesia. This present study aimed to detect and identify the presence of this pathogen by morphological and molecular observation. Morphological observation revealed the presence of teliospores on young Syzygium leaves and the presence of A. psidii urediniospores on salam (Syzygium polyanthum) and kayu putih (Melaleuca cajuputi) leaves collected from the arboretum of the Center for Forest Biotechnology and Tree Improvement (CFBTI)in Yogyakarta, Indonesia. PCR amplification using specific primers of Ppsil / Ppsi6 succeeded in detecting the presence of A. psidii fungi Melaleuca and Syzygium showed by DNA amplicon length around 500bp. Efforts to obtain ITS DNA sequences to compare the molecular characteristics of fungi from two different hosts have been carried out, however, the sequencing electropherogram was unreadable, so the comparison can not be performed. This study reported that A. psidii is currently present in Myrtaceae species in Yogyakarta, therefore precaution efforts should be conducted to avoid economic and ecological impact from this pathogen.
\end{abstract}

Keywords: PCR, molecular markers, species-specific markers, rust fungi

\begin{abstract}
ABSTRAK
Austropuccinia psidii merupakan salah satu jamur patogen penyebab karat pada tanaman famili Myrtaceae. Meningkatnya kegiatan penanaman jenis pohon yang merupakan inang jamur ini telah meningkatkan serangan jamur patogen yang berdampak pada peningkatan ancaman terhadap keberadaan jenis dari famili Myrtaceae di seluruh dunia termasuk di Indonesia. Penelitian ini bertujuan untuk mendeteksi dan mengidentifikasi keberadaan patogen tersebut melalui pengamatan morfologi dan molekuler. Pengamatan morfologi menunjukkan adanya teliospora pada daun salam yang masih muda dan urediniospora jamur A. psidii pada daun salam (Syzygium polyanthum) dan daun kayu putih (Melaleuca cajuputi) yang diambil dari arboretum Balai Besar Penelitian dan Pengembangan Bioteknologi dan Pemuliaan Tanaman Hutan (BBPPBPTH) di Yogyakarta, Indonesia. Amplifikasi PCR menggunakan penanda DNA spesifik untuk jenis A. psidii yaitu Ppsil / Ppsi6 telah berhasil mendeteksi keberadaan jamur $A$. psidii pada kedua jenis tanaman tersebut ditandai dengan adanya amplikon DNA berukuran sekitar 500bp. Upaya memperoleh sekuens DNA ITS untuk membandingkan sifat molekuler fungi dari dua inang yang berbeda telah dilakukan, namun elektropherogram sekuens tersebut tidak terbaca sehingga tidak dapat dilakukan perbandingan. Studi ini melaporkan bahwa serangan jamur A. psidii saat ini terdapat pada dua jenis dari famili Myrtaceae di Yogyakarta, oleh karena itu upaya pencegahan perlu dilakukan untuk menghindari dampak ekonomis dan ekologis dari keberadaan patogen tersebut.
\end{abstract}

Kata kunci: PCR, penanda molekuler, penanda spesifik jenis, jamur karat

\section{PENDAHULUAN}

Austropuccinia psidii sebelumnya dikenal sebagai Puccinia psidii (Beenken, 2017) adalah jamur patogen yang menyerang tumbuhan dari kelompok Myrtaceae. Jamur karat ini menyerang organ muda tanaman seperti daun, bunga, tunas, buah (Tommerup et al., 2003) dan mengakibatkan kerusakan pada organ yang terserang (Glen et al., 2007). Gejala pertama pada tanaman yang terinfeksi jamur A. psidii adalah munculnya bercak klorotik kuning pada organ yang terinfeksi. Setelah beberapa hari, 
pustula yang mengandung uredinia menghasilkan spora kuning yang disebut urediniospora. Penyakit ini dapat menurunkan pertumbuhan tanaman, menyebabkan defoliasi cabang yang parah, deformasi daun dan kematian tanaman (Liberato et al., 2006). Pada tanaman buah famili Myrtaceae seperti jambu biji, A. psidii terbukti menurunkan kualitas buah, memicu infeksi sekunder yang menyebabkan pembusukan buah, dan mengundang datangnya serangga oportunistik untuk menyerang buah (Martins et al., 2014).

Austropuccinia psidii merupakan ancaman bagi penanaman jenis dari famili Myrtaceae di banyak negara dan diprediksi dapat menyebabkan kerugian yang signifikan dalam perdagangan kayu beberapa jenis eukaliptus di Australia (Booth et al., 2000), karena dapat menyebabkan gangguan pertumbuhan, malformasi bahkan kematian pada tanaman muda (Coutinho et al., 1998). Jamur patogen ini pertama kali dilaporkan oleh Winter (1984) menyerang Psidium guajava di Brasil. Setelah dilaporkan pertama kali, patogen ini kemudian ditemukan pada beberapa jenis tumbuhan Myrtaceae di beberapa negara, yaitu pada Metrosideros polymorpha di Hawaii (Uchida et al., 2006), pada Eucalyptus amplifolia dan E. rudis di Jepang (Kawanishi et al., 2009) dan pada Myrtus communis di Afrika (Roux et al., 2013). Ancaman A. psidii bagi hutan tanaman Myrtaceae di Australia telah diprediksi pada tahun 2003 (Old et al., 2003), dan menjadi kenyataan dengan ditemukannya patogen ini pada beberapa tanaman misalnya Agonis flexuosa, Callistemon viminalis dan Syncarpia glomulifera di Australia pada bulan April (Carnegie et al., 2010).

Indonesia sebagai negara mega biodiversitas memiliki 30 marga tumbuhan dari famili Myrtaceae (Craven et al., 2003). Ancaman patogen ini di Indonesia dimulai dengan dilaporkannya pertama kali penemuan A. psidii di Indonesia pada Eucalyptus pellita dan Melaleuca leucadendra yang ditanam di Sumatera Selatan dan Sumatera Utara pada bulan
Juli 2015 (McTaggart et al., 2015). Identifikasi morfologi menunjukkan bahwa patogen yang ditemukan pada pohon tersebut mirip dengan A. psidii yang terdapat di Australia. Konfirmasi identitas jenis jamur yang dilakukan menggunakan penanda rDNA Internal Transcribed Spacer (ITS) mendapatkan bahwa jamur karat yang ditemukan di wilayah Indonesia identik dengan epitype $A$. psidii yang digambarkan oleh Machado et al., pada tahun 2015 (McTaggart et al., 2015). Pada studi karakter molekuler A. psidii yang lebih lanjut telah berhasil dikembangkan penanda spesifik untuk deteksi cepat A. psidii (Bakkeren \& Szabo, 2020; Langrell et al., 2008; Rivera-Orduna et al., 2011).

Gejala penyakit karat A. psidii ditemukan pada beberapa pohon yang ditanam di arboretum Balai Besar Penelitian dan Pengembangan Bioteknologi dan Pemuliaan Tanaman Hutan (BBPPBPTH) di Yogyakarta pada bulan Agustus 2018, saat dilakukan kegiatan survei patogen. Oleh karena itu diperlukan pengamatan lebih lanjut terhadap karakter morfologi dan identifikasi patogen ini untuk memastikan keberadaan dan penyebarannya di Pulau Jawa. Penelitian ini dilakukan untuk mendeteksi dan mengidentifikasi jamur karat yang terdapat pada pohon salam (Syzygium polyanthum) dan kayu putih (Melaleuca cajuputi) dengan menggunakan karakter morfologi dan karakter molekuler.

\section{BAHAN DAN METODE}

\section{A. Pengambilan sampel dan pengamatan karakter morfologi spora}

Pengambilan sampel materi genetik untuk pengamatan morfologi spora dilakukan pada saat survei penyakit karat di arboretum BBPPBPTH pada bulan Agustus tahun 2018. Sampel berupa organ tanaman seperti daun, ranting, dan ranting pohon salam (Syzygium polianthum) dan pohon kayu putih (Melaleuca cajaputi), yang menunjukkan gejala terinfeksi A. psidii diambil menggunakan gunting dan dimasukkan dalam kantong kertas dan dijaga tetap kering dalam 
suhu ruangan hingga dilakukannya pengamatan terhadap karakter morfologi spora. Usapan spora dari satu koloni jamur diambil menggunakan cotton bud yang telah disterilkan. Sampel berupa potongan kecil daun yang mengandung satu koloni jamur juga diambil menggunakan gunting. Sampel spora maupun potongan daun disimpan dalam microtube steril yang telah diisi larutan Sodium Dedesil Sulfat (SDS), untuk disimpan sebelum pengamatan molekuler dilakukan.

Pengamatan morfologi dilakukan terhadap spora yang diperoleh dari tanaman inang yang berbeda. Satu usapan spora dari organ tanaman yang terserang karat diambil menggunakan cotton bud steril kemudian diletakkan pada kaca objek dan spora diwarnai dengan bromo-phenol blue (BPB) dan diamati strukturnya pada beberapa perbesaran mikroskop yang berbeda. Data yang diperoleh dari identifikasi morfologi spora dicatat dan diuji terhadap literatur.

\section{B. Ekstraksi DNA}

Pada bulan Desember 2018 dilakukan pengambilan ulang sampel untuk pengamatan molekuler. Adapun kegiatan analisa DNA dilakukan di laboratorium Genetika Molekuler BBPPBPTH hingga bulan Januari 2018.

Proses ekstraksi DNA dilakukan sesuai dengan prosedur yang digunakan oleh Prihatini (Prihatini et al., 2018). DNA diekstraksi dari spora dan juga dari potongan daun yang mengandung spora $A$. psidii yang telah disimpan di dalam larutan SDS $250 \mu \mathrm{l}$ di dalam microtube $2 \mathrm{~mL}$. Pengukuran kualitas dan kuantitas DNA genomik hasil ekstraksi dilakukan menggunakan spektrofotometer Nanovue Plus (GE Healthcare) pada panjang gelombang $260 \mathrm{~nm}$ dan $280 \mathrm{~nm}$. DNA diencerkan menjadi 5ng sebelum digunakan dalam proses amplifikasi DNA. Pada perlakuan yang lain DNA hasil ekstraksi diencerkan sebanyak 20 kali dan 40 kali menggunakan larutan Tris-EDTA (TE) dan digunakan sebagai ulangan.

\section{Amplifikasi DNA ITS dengan penanda spesifik jenis $A$. psidii dan penanda umum jamur}

Amplifikasi DNA daerah ITS dengan penanda spesifik jenis $A$. psidii dilakukan menggunakan pasangan primer Ppsil / Ppsi6 (Langrell et al., 2008) Reaksi PCR dilakukan pada mesin GeneAmp 9700 PCR (Applied Biosystem). Reaksi PCR terdiri dari 12,5 $\mu \mathrm{L}$ MyTaq Red Mix (Bioline), primer forward dan reverse konsentrasi $25 \mu \mathrm{M}$ masing-masing sebanyak $0,625 \mu \mathrm{L}$, template DNA sebanyak $5 \mu \mathrm{L}$ dan air steril untuk membuat volume mencapai $25 \mu \mathrm{L}$. Kondisi suhu pada proses PCR adalah sebagai berikut: denaturasi awal dengan suhu $94^{\circ} \mathrm{C}$ selama 3 menit, dilanjutkan dengan 30 siklus PCR yang terdiri dari denaturasi DNA pada suhu $94^{\circ} \mathrm{C}$ selama 1 menit, annealing pada suhu $57^{\circ} \mathrm{C}$ selama 1 menit dan extension atau pemanjangan DNA pada suhu $72^{\circ} \mathrm{C}$ selama 1 menit, dan diakhiri dengan proses ekstensi akhir dengan suhu $72^{\circ} \mathrm{C}$ selama 10 menit (Langrell et al., 2008).

Amplifikasi DNA daerah ITS dilakukan menggunakan pasangan primer umum atau universal untuk jamur yaitu ITS1F / ITS4 (Gardes \& Bruns, 1993; White et al., 1990). Kondisi suhu pada proses PCR dengan penanda universal fungi sedikit berbeda dengan kondisi PCR dengan penanda spesifik A. psidii. Suhu yang digunakan adalah sebagai berikut: denaturasi awal DNA pada suhu $94^{\circ} \mathrm{C}$ selama 5 menit, 30 siklus amplifikasi yang terdiri dari 30 detik pada suhu $94^{\circ} \mathrm{C}, 30$ detik pada suhu $55^{\circ} \mathrm{C}$, dan 60 detik pada suhu $72^{\circ} \mathrm{C}$, diikuti 7 menit untuk proses pemanjangan sekuen DNA pada suhu $72^{\circ} \mathrm{C}$.

Amplikon DNA yang dihasilkan dari kedua proses PCR dipisahkan dengan elektroforesis dalam gel agaros $1 \%$ dan dijalankan selama \pm 1 jam, dengan aliran arus 100 V dan hasilnya divisualisasikan menggunakan mesin dokumentasi gel dan software Quantity One Basic (Biorad). Amplikon DNA rITS yang diperoleh dari penggunaan 
penanda umum jamur kemudian digunakan untuk sequensing.

\section{Sequencing ITS DNA and analisis data}

Produk amplifikasi DNA ITS dengan penanda ITSIF / ITS4 dikirim ke Perusahaan sequensing DNA 1st Base untuk proses sequensing DNA. Sebelum dilakukan sequencing, dilakukan pengujian kualitas dan kuantitas DNA menggunakan gel agarose dan amplikon DNA diekstraksi kembali dari gel agarose dan dilakukan pemurnian DNA. Kromatogram sekuen DNA yang diperoleh melalui akses pada website 1st Base diamati dan diedit menggunakan software Chromas (http://technelysium.com.au/wp/chromas).

Pengeditan sekuen DNA dilakukan untuk mengambil sekuen DNA hanya pada bagian ITS1, 5.8S dan ITS2. Sekuen DNA sampel yang dihasilkan dari penelitian ini kemudian dipastikan kecocokkannya dengan sekuen DNA jamur A. psidii yang tersedia di database National Center for Biotechnology Information (NCBI) menggunakan program Basic Local Alignment Search Tool (BLAST). Sekuen DNA dengan kualitas kromatogram yang baik diselaraskan menggunakan ClustalW
(Thompson et al., 1994) pada software Bioedit versi 7.0.5.3 (Hall, 1999).

\section{HASIL DAN PEMBAHASAN}

Gejala penyakit karat ditemukan pada pohon salam dan kayu putih yang terdapat pada sisi luar arboretum BBPPBPTH. Pada pengamatan lebih lanjut, spora A. psidii banyak ditemukan pada daun muda (Gambar 1) dan jarang ditemukan pada daun tua. Hal ini sesuai dengan ditemukan pada tanaman Eucalyptus (Glen et al., 2007; Pérez et al., 2011) yaitu infeksi ditemukan sebagian besar pada jaringan muda yang sedang tumbuh meskipun juga dapat ditemukan pada daun dewasa. Sebuah penelitian yang membandingkan perkecambahan urediniospora pada jaringan muda dan jaringan dewasa daun Eucalyptus grandis, menyimpulkan bahwa lapisan kutikula dan lapisan lilin yang lebih tebal berhubungan dengan lebih sedikitnya infeksi A. psidii pada daun tua dibandingkan pada daun yang lebih muda (Xavier et al., 2015). Tebalnya lapisan kutikula dan lapisan lilin pada daun yang lebih tua membuat pembentukan apresorium jamur lebih sulit dilakukan. Kegagalan pembentukan apresorium menyebabkan tidak terjadinya penetrasi jamur ke dalam daun (Xavier et al., 2015).
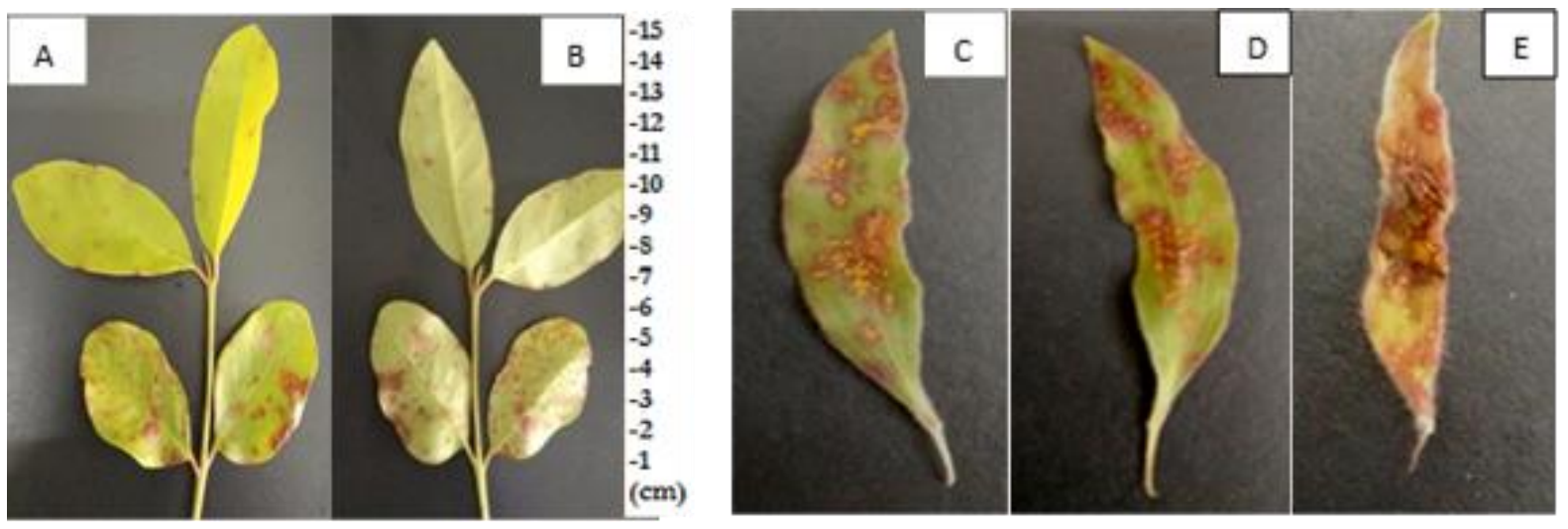

Gambar 1. Gejala yang muncul dari serangan jamur Austropuccinia psidii pada daun yang masih muda A. Permukaan atas daun salam, B. Permukaan bawah daun salam C. Permukaan atas daun kayu putih, D. Permukaan bawah daun kayu putih, E. Daun tunas muda kayu putih yang mati.

\section{A. Pengamatan karakter morfologi spora}

Spora A. psidii diamati menggunakan mikroskop dengan perbesaran 1000 kali. Pada pengamatan urediniospora, digunakan pewarna Bromophenol blue. Urediniospora yang teramati pada tanaman salam dan kayu putih berbentuk 
bulat telur, uniseluler, dengan dinding spora transparan (Gambar 2). Hal ini sesuai dengan gambaran yang disampaikan oleh Hernández (Hernandez, 2006). Menurut Perez et al. (Pérez et al., 2011), urediniospora A. psidii memiliki ukuran 19-26 x 15-22 $\mu \mathrm{m}$ dan memiliki duri yang halus dan seragam pada luar dinding selnya, panjang duri tersebut $1 \mu \mathrm{m}$, dan antara satu duri dan lainnya terpisah dengan jarak $0,5-1,5 \mu \mathrm{m}$.

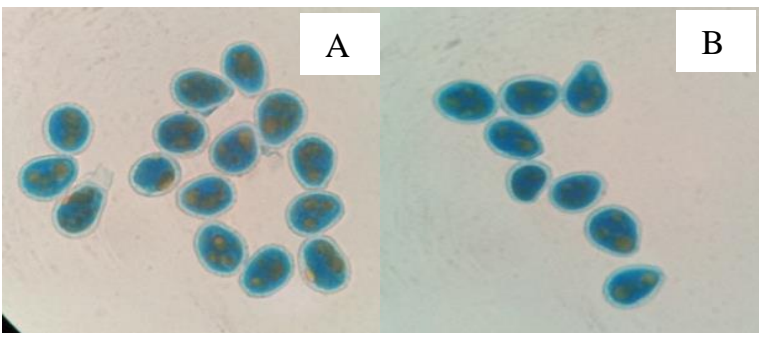

Gambar 2. Urediniospora Austropuccinia psidii yang ditemukan pada daun salam (A) dan daun kayu putih (B).

Pada penelitian ini, teliospora yang merupakan tahap perkembangan lanjutan dari urediniospora hanya teramati pada daun salam. Pengamatan menggunakan mikroskop dengan perbesaran 400x, teramati teliospora berwarna kuning pucat, berbentuk oval, memiliki satu septat dan mengandung dua sel terpisah dengan sel atas lebih lebar dan lebih pendek dari pada sel bawah (Gambar 3). Gambaran teliospora ini sesuai dengan hasil pengamatan yang dilakukan pada penelitian sebelumnya oleh Walker et al.(Walker, 1983).

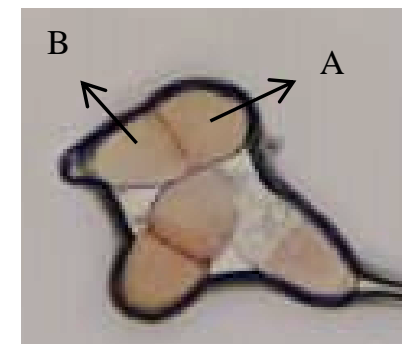

Gambar 3. Teliospora dari Austropuccinia psidii pada daun salam yang terdiri dari sel atas (A) dan sel bawah (B)

B. Deteksi menggunakan penanda spesifik untuk jamur Austropuccinia psidii (Primer Ppsi1 / Ppsi6)

Proses amplifikasi DNA jamur yang diambil dari daun salam dan kayu putih keduanya menunjukkan adanya amplikon DNA berukuran sekitar 500 bp (Gambar 4). Pada penelitian lain yang telah dilakukan, amplifikasi menggunakan primer Ppsi1 / Ppsi6 untuk mendeteksi adanya jamur A. psidii pada beberapa jenis dari famili Myrtaceae juga menghasilkan amplikon berukuran sekitar 500 bp (Langrell et al., 2008). Hal ini menunjukkan bahwa spora yang teramati pada penelitian ini adalah spora jamur A. psidii.

Deteksi jamur A. psidii dapat dilakukan menggunakan sampel berupa spora maupun daun yang mengandung spora (Gambar 4). Namun sampel berupa daun yang mengandung spora memberikan hasil positif deteksi pada kedua jenis tanaman pada hampir semua ulangan daun dan konsentrasi DNA yang berbeda (data pengukuran konsentrasi DNA tidak ditunjukkan). Hanya dua dari tiga ulangan daun kayu putih (K1, K2) pengenceran DNA 20 kali dan satu ulangan daun (K1) pengenceran DNA 40 kali yang tidak menunjukan adanya amplikon DNA. Penggunaan sampel spora untuk mendeteksi jamur A. psidii juga tidak dipengaruhi oleh konsentrasi DNA pada reaksi PCR.

Perbedaan kualitas amplikon DNA jamur A. psidii yang dihasilkan oleh penanda spesifik Ppsi1/Ppsi6 mungkin disebabkan karena kualitas DNA yang tidak terlalu bagus meskipun rasio DNA hasil ekstraksi yang terukur menggunakan spektrofotometer tidak berbeda jauh antar sampel (data pengukuran rasio DNA tidak ditunjukkan). Hal ini juga ditemukan pada penelitian yang dilakukan oleh Langrell et al. (Langrell et al., 2008) yang tidak mendapatkan amplikon DNA jamur A. psidii dari sampel tunas, pollen, biji dan buah beberapa jenis inang famili Myrtaceae menggunakan penanda Ppsil/Ppsi6. Upaya berikut yang dilakukan adalah pengunaan metode nested PCR dengan penanda Ppsi2/Ppsi4 dan berhasil mendapatkan amplikon dengan ukuran yang lebih kecil yaitu sekitar $380 \mathrm{bp}$ (Langrell et al., 2008). Pendekatan nested PCR dilakukan untuk mendapatkan hasil deteksi yang lebih akurat dan spesifik. Proses ini pada dasarnya sama dengan PCR namun template 
DNA yang digunakan merupakan amplikon dari PCR sebelumnya. Metode nested juga dilakukan oleh Baskarathevan et al. (Baskarathevan et al., 2016), dimana amplifikasi dengan penanda Ppsil/Ppsi6 tidak menghasilkan amplikon A. psidii yang diharapkan, namun deteksi lebih lanjut menggunakan metode nested PCR dengan penanda Ppsi2/Ppsi4 menghasilkan amplikon berukuran kurang lebih 380 bp. Namun pada penelitian ini metode nested PCR tidak dilakukan karena penggunaan penanda spesifik Ppsil/Ppsi6 sudah mampu mendeteksi adanya jamur A. psidii pada dua jenis tanaman yang diamati meskipun tidak selalu muncul pada semua ulangan. Hal ini menunjukkan bahwa A. psidii dapat terdeteksi menggunakan penanda spesifik Ppsil/Ppsi6 pada sampel berupa spora maupun daun yang mengandung spora, pada daun salam dan kayu putih, pada beberapa konsentrasi DNA yang berbeda.

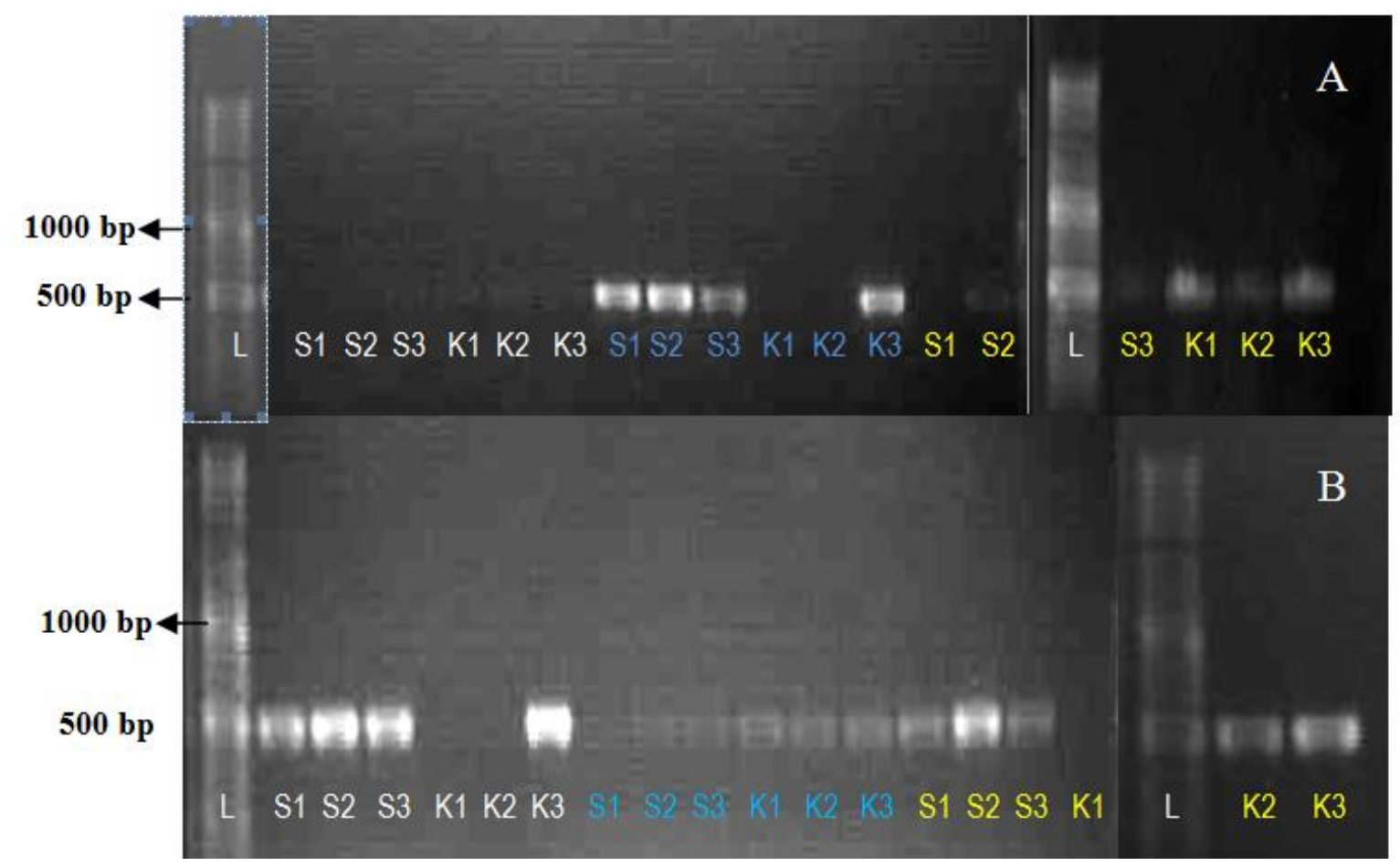

Gambar 4. Amplikon DNA yang dihasilkan oleh penanda spesifik (Ppsil/Ppsi6) untuk jenis Austropuccinia psidii dari sampel spora (A) dan daun yang mengandung spora (B) pada pohon salam (S) dan pohon kayu putih $(\mathrm{K})$. Deteksi dilakukan pada tiga ulangan sampel $(1,2,3)$, tiga ulangan konsentrasi DNA (pengenceran 20 kali (huruf warna putih), pengenceran 40 kali (huruf warna biru), DNA sebanyak $5 \mathrm{ng} / \mu \mathrm{l}$ (huruf warna kuning). L adalah 100bp DNA ladder

\section{Identifikasi jamur pathogen dengan penanda umum jamur dan analisa sequensing DNA ITS}

Amplifikasi DNA ITS jamur A. psidii juga dilakukan menggunakan penanda ITS1F/ITS4 untuk dilanjutkan dalam proses sequensing DNA. Tidak semua sampel DNA digunakan dalam tahapan sequensing, namun hanya sampel spora yang berasal dari kedua jenis tanaman saja untuk menghindari kontaminasi jamur lain yang terambil dari sampel daun. Sampel DNA dengan pengenceran sebanyak 20 kali dipilih untuk digunakan pada tahapan ini.
Amplifikasi DNA ITS menggunakan penanda ITS1F/ITS4 dari sampel spora yang ditemukan pada pohon salam dan kayu putih menunjukkan hasil positif dengan terlihatnya pita DNA terang yang berukuran 700 bp (Gambar 5), namun juga teramati adanya pita DNA kedua yang lebih samar dan berukuran 600 bp. Hal ini menunjukkan bahwa meskipun menggunakan sampel DNA dari spora jamur tertentu namun kontaminasi oleh adanya jamur lain masih dapat terjadi. Untuk mengatasi terjadinya kontaminasi pada proses sequensing DNA, dilakukan pemisahan pita ganda DNA 
melakukan proses elektroforosis menggunakan agaros lebih lama. DNA dari pita tunggal yang telah terpisahkan pada agarose diambil dan digunakan dalam proses sequensing DNA untuk mengidentifikasi jenis jamurnya dan melihat variasi karakter sekuen DNA ITS antara jamur yang ditemukan pada pohon salam dan kayu putih

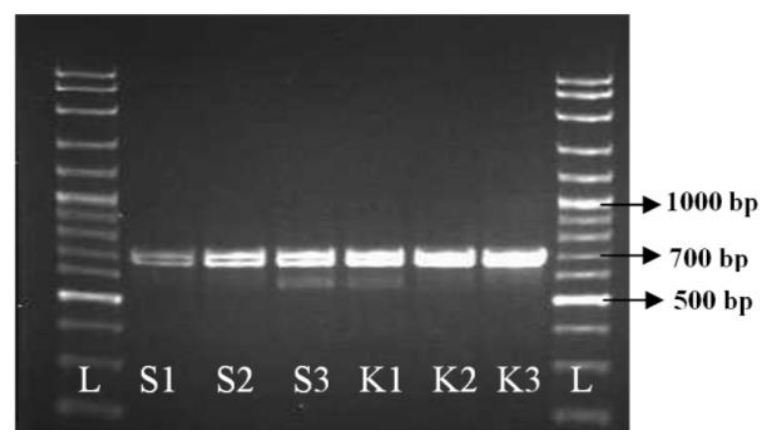

Gambar 5.Amplikon DNA ITS amplicon Austropucinia psidii dari sampel spora yang terdapat pada pohon salam (S) dan kayu putih (K), dengan tiga kali ulangan $(1,2,3)$. L adalah 100bp DNA ladder

Sekuen DNA ITS banyak digunakan untuk identifikasi jenis jamur yang sulit dibedakan dengan karakter morfologi saja dan telah disepakati sebagai salah satu penanda DNA untuk barcoding oleh Consortium for the Barcode of Life (Bellemain et al., 2010; Raja et al., 2017). Daerah ITS dipilih karena memiliki variasi yang tinggi pada satu genus (Gomes et al., 2002), namun juga dapat menunjukkan adanya perbedaan di antara banyak jenis jamur karat (Langrell et al., 2008). Dalam penelitian yang dilakukan oleh Schoch et al. (Schoch et al., 2012) yang membandingkan penanda DNA ITS, LSU, SSU, dan RPB1, menemukan bahwa daerah ITS merupakan penanda yang menghasilkan peluang keberhasilan identifikasi jenis jamur tertinggi di antara penanda lainnya karena memiliki barcoding gap yang paling jelas, meskipun pada beberapa kelompok tertentu diperlukan penanda tambahan.

Hasil sequensing DNA pada penelitian ini meskipun telah menggunakan pita DNA tunggal sebagai amplikon DNA untuk proses sequensing belum bisa mendapatkan kromatogram yang jelas (Gambar tidak ditampilkan). Masih terlihat adanya basa nukleotida dari DNA kontaminan yang menumpuk dengan basa nukleotida dari DNA sampel, sehingga urutan DNA tidak bisa dibaca dengan jelas. Namun upaya mencari kemiripan dengan metode BLAST tetap dilakukan. Satu sampel DNA dari spora pada pohon salam ulangan 1 yang memiliki $98 \%$ query cover menunjukkan adanya kemiripan tertinggi yaitu sebesar 94.27\% (625/663) dengan sekuen ITS jamur A. psidii (EU348742) yang ditemukan pada Eucalyptus grandis dari Uruguay (Pérez et al., 2011). Suatu jenis jamur dapat dipastikan sebagai jamur $A$. psidii jika memiliki kemiripan lebih dari 98\% (Rodas et al., 2015), oleh karena itu sampel spora tersebut meskipun teramplifikasi menggunakan penanda DNA ITS1F/ITS4 belum dapat dipastikan jenisnya. Penggunaan primer tersebut memerlukan tahapan lebih lanjut yaitu proses sequensing DNA dan melihat kemiripannya dengan sekuen DNA dari isotype jamur atau isolat lain yang telah ada pada data basa DNA.

Selain untuk identifikasi jenis, sekuen DNA juga dapat digunakan untuk melihat adanya variasi antar individu. Perbedaan variasi genetik patogen serta tingkat patogenisitas tiap individu atau isolat perlu dipelajari untuk merencanakan upaya pengendalian penyakit. Adanya perbedaan variasi genetik dan tingkat patogenisitas $A$. psidii teramati di Uruguay meskipun dalam jumlah sampel yang sedikit (Pérez et al., 2011).

Meskipun upaya identifikasi jenis jamur menggunakan penanda ITS universal jamur (ITS1F/ITS4) maupun penanda spesifik belum dapat dilakukan pada penelitian ini, namun keberadaan jamur patogen A. psidii telah terdeteksi pada pohon salam dan kayu putih yang ada di Yogyakarta. Penelitian ini merupakan laporan pertama mengenai jamur A. psidii di Pulau Jawa, dan penelitian kedua yang melaporkan keberadaan jamur ini di Indonesia. Hingga penelitian ini dilaporkan, belum ditemukan gejala penyakit karat yang disebabkan oleh A. psidii pada jenis lain di sekitar Yogyakarta. Sebaran kedua jenis pohon tersebut 
sangat luas karena merupakan jenis tanaman yang penting dan banyak ditanam di Indonesia karena memiliki manfaat untuk pengobatan dan juga digunakan sebagai bahan tambahan makanan. Kayu putih saat ini sedang dikembangkan (Sumardi et al., 2018) untuk budidaya bersama dengan kelompok tani diberbagai tempat di Indonesia sebagai sumber bahan baku industri minyak kayu putih di Indonesia (KLHK, 2020). Untuk itu perlu antisipasi penyebaran penyakit karat pada beberapa jenis dari famili Myrtaceae khususnya anakan kayu putih yang ditanam di beberapa wilayah di Indonesia perlu dilakukan.

Penelitian lebih lanjut mengenai sebaran A. psidii yang ada di wilayah lain di Pulau Jawa dan Pulau lain di Indonesia, variasi genetik antar individu dari berbagai inang dan wilayah yang berbeda serta tingkat serangan (patogenisitas) individu perlu dilakukan, sehingga upaya pengendalian dan pencegahan penyebaran penyakit dapat dilakukan secara optimal.

\section{KESIMPULAN}

Penggunaan penanda spesifik Ppsil/Ppsi6 telah mendeteksi adanya jamur pathogen A. psidii pada pohon salam dan kayu putih yang ada di arboretum BBPPBPTH Yogyakarta. Adapun identifikasi variasi genetik menggunakan penanda DNA umum jamur ITS1F/ITS4 belum dapat dilakukan karena adanya kontaminasi DNA.

\section{UCAPAN TERIMA KASIH}

Penelitian ini dilakukan dengan memanfaatkan anggaran DIPA tahun 2018-2019. Farah Aulya Faradilla adalah mahasiswa tingkat Sarjana Program Studi Biologi Fakultas Matematika dan Ilmu Pengetahuan Alam, Universitas Sebelas Maret Surakarta yang melakukan penelitian skripsi pada BBPPBPTH di Yogyakarta. Penulis mengucapkan terima kasih kepada semua pihak yang telah membantu dalam kegiatan penelitian ini.

\section{DAFTAR PUSTAKA}

Bakkeren, G., \& Szabo, L. J. (2020). Progress on molecular genetics and manipulation of rust fungi. Phytopathology, 110(3), 532-543. https://doi.org/10.1094/PHYTO-07-19-0228IA

Baskarathevan, J., Taylor, R. K., Ho, W., McDougal, R. L., Shivas, R. G., \& Alexander, B. J. R. (2016). Real-time PCR assays for the detection of Puccinia psidii. Plant Disease, 100(3), 1-8. https://doi.org/10.1094/PDIS-0815-0851-RE

Beenken, L. (2017). Austropuccinia: A new genus name for the myrtle rust $P$ uccinia psidii placed within the redefined family Sphaerophragmiaceae (Pucciniales). Phytotaxa, 297(1), 53-61. https://doi.org/10.11646/phytotaxa.297.1.5

Bellemain, E., Carlsen, T., Brochmann, C., Coissac, E., Taberlet, P., \& Kauserud, H. (2010). ITS as an environmental DNA barcode for fungi: an in silico approach reveals potential PCR biases. BMC Microbiology, 10.

Booth, T. H., Old, K. M., \& Jovanovic, T. (2000). A preliminary assessment of high risk areas for Puccinia psidii (Eucalyptus rust) in the Neotropics and Australia. Agriculture, Ecosystems and Environment, 82(1-3), 295301 8809(00)00233-4 https://doi.org/10.1016/S0167-

Carnegie, A. J., Lidbetter, J. R., Walker, J., Horwood, M. A., Tesoriero, L., Glen, M., \& Priest, M. J. (2010). Uredo rangelii, a taxon in the guava rust complex, newly recorded on Myrtaceae in Australia. Australasian Plant Pathology, $39(5)$, 463-466. https://doi.org/10.1071/AP10102

Coutinho, T. A., Wingfield, M. J., Alfenas, A. C., \& Crous, P. W. (1998). Eucalyptus rust: A disease with the potential for serious international implications. Plant Disease, 82(7),

819-825. https://doi.org/10.1094/PDIS.1998.82.7.819

Craven, L. A., Sunarti, S., Mudiana, D., Yulistyarini, T., \& Wardani, M. (2003). Identification key to the indigenous Indonesian genera of Myrtaceae. Floribunda, 24, 89-94.

Gardes, M., \& Bruns, T. D. (1993). ITS primers with enhanced specificity for basidiomycetes, application to the identification of mycorrihiza and rusts. Molecular Ecology, 2(May 2016), 113-118. https://doi.org/Doi 10.1111/J.1365294x.1993.Tb00005.X

Glen, M., Alfenas, A. C., Zauza, E. A. V, Wingfield, M. J., \& Mohammed, C. (2007). Puccinia 
psidii: a threat to the Australian environment and economy - a review. Australasian Plant Pathology, 36(1), 1-16. https://doi.org/10.1071/AP06088

Gomes, E. A., Kasuya, M. C. M., de Barros, E. G., Borges, A. C., \& Fernandes de Araújo, E. (2002). Polymorphism in the internal transcribed spacer (ITS) of the ribosomal DNA of 26 isolates of ectomycorrhizal fungi. Genetics and Molecular Biology, 25(4), 477$483 . \quad$ https://doi.org/10.1590/S141547572002000400018

Hall, T. A. (1999). BioEdit: A user-friendly biological sequence alignment editor and analysis program for Windows 95/98/NT. Nucleic Acids Symposium Series, 41, 95-98.

Hernandez, J. R. (2006). Invasive fungi fact sheets. Puccinia psidii. Systemic Mycology and Microbiology Laboratory ARS USDA.

Kawanishi, T., Uematsu, S., Kakishima, M., Kagiwada, S., Hamamoto, H., Horie, H., \& Namba, S. (2009). First report of rust disease on ohia and the causal fungus, Puccinia psidii, in Japan. Journal of General Plant Pathology, 75(6), 428-431. https://doi.org/10.1007/s10327-009-0202-0

KLHK. (2020). Hilirisasi Benih Unggul Kayuputih Berbasis Kelompok Tani.

Langrell, S. R. H., Glen, M., \& Alfenas, A. C. (2008). Molecular diagnosis of Puccinia psidii (guava rust) - A quarantine threat to Australian eucalypt and Myrtaceae biodiversity. Plant Pathology, 57(4), 687-701. https://doi.org/10.1111/j.13653059.2008.01844.x

Liberato, J. R., Silveira, S. F., Junghans, D. T., Rocabado, J. A., Aperecido, C., \& Shivas, R. G. (2006). Eucalyptus rust. PaDIL.

Martins, M. V., da Silveira, S. F., \& Maffia, L. A. (2014). Guava fruit loss caused by rust. Summa Phytopathologica, 40(2), 107-113. https://doi.org/10.1590/0100-5405/1904

McTaggart, A. R., Doungsa-Ard, C., Geering, A. D. W., Aime, M. C., \& Shivas, R. G. (2015). A co-evolutionary relationship exists between Endoraecium (Pucciniales) and its Acacia hosts in Australia. Persoonia: Molecular Phylogeny and Evolution of Fungi, 35(1), 5062.

https://doi.org/10.3767/003158515X687588

Old, K. M., Wingfield, M. J., \& Yuan, Z. Q. (2003). A manual of diseases of eucalypts in SouthEast Asia. In Center for International Forestry Research.
Pérez, C. A., Wingfield, M. J., Altier, N. A., Simeto, S., \& Blanchette, R. A. (2011). Puccinia psidii infecting cultivated Eucalyptus and native Myrtaceae in Uruguay. Mycological Progress, 10(3), 273-282. https://doi.org/10.1007/s11557-010-0698-X

Prihatini, I., Rimbawanto, A., Puspitasari, D., \& Fauzi, D. (2018). Pengujian penanda jenis spesifik pada jamur yang berpotensi sebagai agens pengendali hayati penyakit busuk akar pada akasia. Jurnal Pemuliaan Tanaman Hutan; Vol 12, No 1 (2018): Jurnal Pemuliaan Tanaman Hutan. https://doi.org/10.20886/jpth.2018.12.1.1-12

Raja, H. A., Miller, A. N., Pearce, C. J., \& Oberlies, N. H. (2017). Fungal identification using molecular tools: A primer for the natural products research community. Journal of Natural Products, 80(3), 756-770. https://doi.org/10.1021/acs.jnatprod.6b01085

Rivera-Orduna, F. N., Suarez-Sanchez, R. A., FloresBustamante, Z. R., Gracida-Rodriguez, J. N., \& Flores-Cotera, L. B. (2011). Diversity of endophytic fungi of Taxus globosa (Mexican yew). Fungal Diversity, 47(1), 65-74.

Rodas, C. A., Roux, J., Maier, W., Granados, G. M., Bolaños, M. D., Mctaggart, A. R., \& Wingfield, M. J. (2015). First report of Puccinia psidii on Corymbia citriodora and Eucalyptus in Colombia. Forest Pathology, 45(6), 534-536. https://doi.org/10.1111/efp.12223

Roux, J., Greyling, I., Coutinho, T. A., Verleur, M., \& Wingfeld, M. J. (2013). The Myrtle rust pathogen, Puccinia psidii, discovered in Africa. IMA Fungus, 4(1), 155-159. https://doi.org/10.5598/imafungus.2013.04.01 .14

Schoch, C. L., Seifert, K. A., Huhndorf, S., Robert, V., Spouge, J. L., Levesque, C. A., Chen, W., Bolchacova, E., Voigt, K., Crous, P. W., Miller, A. N., Wingfield, M. J., Aime, M. C., An, K. D., Bai, F. Y., Barreto, R. W., Begerow, D., Bergeron, M. J., Blackwell, M., ... Schindel, D. (2012). Nuclear ribosomal internal transcribed spacer (ITS) region as a universal DNA barcode marker for Fungi. Proceedings of the National Academy of Sciences of the United States of America, 109(16), 6241-6246.

Sumardi, S., Kartikawati, N. K., Prastyono, P., \& Rimbawanto, A. (2018). Seleksi dan perolehan genetik pada uji keturunan generasi kedua kayuputih (Melaleuca cajuputi subsp. cajuputi) di Gunung Kidul. Jurnal Pemuliaan Tanaman Hutan, 12(1), 65-73. https://doi.org/10.20886/jpth.2018.12.1.65-73 
Thompson, J. D., Higgins, D. G., \& Gibson, T. J. (1994). CLUSTAL W: improving the sensitivity of progressive multiple sequence alignment through sequence weighting, position-specific gap penalties and weight matrix choice. Nuc.Acid. Res., 22, 4673-4680.

Tommerup, I. C., Alfenas, A. C., \& Old, K. M. (2003). Guava rust in Brazil - A threat to Eucalyptus and other myrtaceae. New Zealand Journal of Forestry Science, 33(3), 420-428.

Uchida, J., Zhong, S., \& Killgore, E. (2006). First report of a rust disease on ohia caused by Puccinia psidii in Hawaii. Plant Disease, 90(4), 524-524. https://doi.org/10.1094/pd$90-0524 \mathrm{c}$

Walker, J. (1983). Pacific mycogeography: deficiencies and irregularities in the distribution of plant parasitic fungi. Australian
Journal of Botany, Supplementary Series, 10(10), 89-136.

White, T. J., Bruns, T., Lee, S., \& Taylor, J. (1990). Amplification and direct sequencing of fungal ribosomal RNA genes for phylogenetics. In PCR protocols: A guide to methods and applications. Academic Press, Inc.

Winter, G. (1984). Rabenhorstii fungi europaei et extraeuropaei exsiccati cura Dr. G. Winter. Centuria XXXV et XXXVI. Hedwigia, 23, 164-165.

Xavier, A. A., da Silva, A. C., da Silva-Guimarães, L. M., Matsuoka, K., Hodges, C. S., \& Alfenas, A. C. (2015). Infection process of Puccinia psidii in Eucalyptus grandis leaves of different ages. Tropical Plant Pathology, 40(5), 318$325 . \quad$ https://doi.org/10.1007/s40858-0150043-7 